\title{
Makna dan fungsi tuturan register dalam games online "mobile legend" serta pengaruhnya bagi gamers
}

\author{
Elen Inderasari ${ }^{a, 1^{*}}$, Kalpika Cahya Buanab,2*, Riza Mar'atus Sholikhah ${ }^{c, 3}$

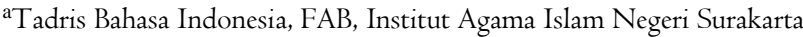

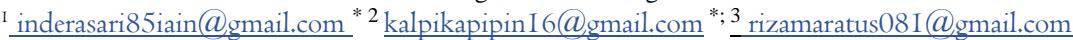 \\ *korespondensi penulis
}

\begin{tabular}{ll}
\hline Informasi artikel & \\
\hline Sejarah artikel: & \\
Diterima & $:$ 23 Januari 2020 \\
Revisi & $:$ 20 April 2020 \\
Dipublikasikan & $:$ 30 April 2020 \\
\hline
\end{tabular}

Kata kunci:

Makna Tuturan, Fungsi Tuturan, Register dalam Games, Mobile Legend.

\begin{abstract}
ABSTRAK
Mobile Legend salah satu jenis permainan games online yang mengunakan komunikasi antar pemainnya. Tujuan penelitian ini adalah untuk mengetahui bentuk, makna dan fungsi tuturan register yang dilontarkan gamers pada saat sedang bermain games Mobile Legend, serta untuk mengetahui dampak positif dan negatif bagi gamers. Jenis penelitian ini deskriptif kualitatif, yaitu mendeskripsikan data-data yang diperoleh. Data penelitian ini adalah bentuk tuturan yang digunakan para gamers dalam Mobile Legend. Data diperoleh dari menyimak, mencatat, dan dokumentasi. Analisis data dalam penelitian ini dilakukan dengan pengumpulan data, mereduksi data, mengklasifikasikan data, menyajikan data, dan menyimpulkan data. Berdasarkan hasil yang didapat bahwa terdapat berbagai jenis tuturan register yang masing-masing menggandung makna khusus yang telah disepakati dan dipahami oleh keduabelah pihak antar pemain Games Mobile Legend sehingga komunikasi efektif. Adapun fungsi tuturan yang disampaikan tak lain untuk mejalin komunikasi sehingga pertandingan berjalan dengan lancar. Berdasarkan fungsinya dapat diklasifikasikan berdasarkan fungsi tuturannya, yang dibagi menjadi 7 kategori, yakni tuturan yang berfungsi untuk memperingatkan tim karena sedang diserang, mengajak untuk bermain games Mobile Legend, memerintah tim untuk menyerang atau mundur, memuji tim atau pemain lain, mengkritik tim atau pemain lain, menyatakan kemenangan tim, dan menyatakan kekalahan tim. Adapun pengaruh baik dan buruknya permainan ini pada pemain dari segi dalam bahasa, tindakan, berpikir, dan bersisosial terhadap lingkungan
\end{abstract} sekitar.

\section{ABSTRACT}

Key word:

The Meaning of Speech, Speech

Function, Register in Games, Mobile Legend.

\begin{abstract}
Mobile Legend is a type of online games that uses communication between players. The purpose of this study was to determine the form, meaning and function of register speech that gamers made when playing Mobile Legend games, and to determine the positive and negative impacts for gamers. This type of research is descriptive qualitative, which describes the data obtained. This research data is the form of speech used by gamers in Mobile Legend. Data obtained from listening, taking notes, and documentation. Data analysis in this research was done by collecting data, reducing data, classifying data, presenting data, and concluding data. Based on the results obtained that there are various types of register speeches, each of which contains a special meaning that has been agreed upon and understood by both parties between Games Mobile Legend players so that communication is effective. The speech function delivered is nothing but to establish communication so that the match runs smoothly. Based on its function, it can be classified based on its speech function, which is divided into 7 categories, namely speech that serves to warn the team because it is being attacked, invite to play Mobile Legend games, order the team to attack or retreat, praise the team or other players, criticize other teams or players, declare the team's victory, and declare the team's defeat. The good and bad effects of this game on players in terms of language, action, thinking, and social to the surrounding environment.
\end{abstract}

\section{Pendahuluan}

Di era kehidupan yang identik dengan penggunaan teknologi ini, banyak orang yang menggunakan kecanggihan teknologi sebagai
Copyright (C) 2018 Universitas Ahmad Dahlan. All Right Reserved pemenuh dan alat bantu di dalam kehidupannya. Perkembangan teknologi merambah pula dalam media game online yang ada di media internet. Penelitian ini lebih memfokuskan penggunaan tuturan 
pada game online. Kini games online tidak hanya menjadi sebuah hiburan semata, permainan menjadi kegemaran banyak orang diberbagai kalangan, dari kalangan muda hingga tua dengan berbagai latar belakang yang berbeda. Salah satu permainan games online yang terkenal menjadi pembahasan penelitian ini adalah games Mobile Legend (ML).

Games online Mobile Legend merupakan permainan battle royale, yaitu pertarungan antara tim satu melawan tim musuhnya. dalam setiap permainan terdapat 10 orang pemain dengan lima orang pemain setiap tim. Permainan ini dapat dimainkan dengan gawai android, sehingga memudahkan Gamers untuk bermain di mana pun dan kapan pun dia berada. Permainan games Mobile Legend ini harus menggunakan data seluler untuk bisa memainkannya. Hasil dari pemberitaan laman Liputan6.com, Negara Indonesia memiliki pemain dan akun aktif mencapai 50 juta sebagai penggunaan games online Mobile Legend, pernyataan tersebut diutarakan Dimaz Wiratama S. Indonesia juga merupakan negara penyumbang terbesar dalam kontribusi permainan Mobile Legend secara tepat, yakni dengan melakukan registrasi sebelum memainkannya dengan jumlah total pengguna aktifnya sebesar 170 juta per bulan di seluruh dunia. Selain itu, permaian ini memiliki 200 juta lebih pengguna yang teregistrasi secara global, dengan 70 juta diantaranya berasal dari Indonesia. (Sumber : https://m.liputan6.com/ tekno/read/3637I59/pengembang-mobile-legendsbakal-buka-markas-di-indonesia).

Kemenarikan games Mobile Legend untuk diteliti, karena dalam kegiatan games tersebut terdapat banyak tuturan sebagai alat komunikasi antar pemainnya. Namun komunikasi yang digunakan ini tidak banyak orang yang tahu. Tentu jika sama-sama seorang gamers maka tanpa dijelaskan pun akan mengetahui maksud yang disampaikan karena bersifat tuturan situasional games. Tuturan tersebut tidak akan bisa mudah dipahami oleh orang awam yang bukan seorang gamers, sebab tuturan bersifat situasi emosional sesama pemain dalam gamers Mobile Legend. Tuturan itu digunakan untuk menyampiakan pesan yang dimaksudkan penutur sebagai ekspresi kepada mitra tuturnya sesama gamers. Wujud tuturan yang dilontarkan biasanya menggunakan bahasabahasa khusus. Dalam berkomunikasi, seorang penutur perlu memperhatikan, yaitu kaidah bahasa yang berlaku dan prinsip penggunaan bahasa itu di dalam suatu peristiwa tutur tertentu (Isnaniah, 20I3). Menurut Rosita dan Dwi (2019: 129) sebuah kegiatan komunikasi dapat terjadi apabila pelaku komunikasi atau penutur dan mitra tutur melakukan kegiatan memperhatikan, melihat, dan mendengar satu sama lain melalui suatu ujaran atau tuturan.
Tuturan tidak dapat dipisahkan dari adanya tindak tutur, keduanya dapat diartikan sebagai satu kesatuan.

Tindak tutur dalam peristiwa tutur merupakan proses komunikasi. Dalam kehidupan sehari-hari, manusia pasti melakukan peristiwa tutur dengan tujuan antara penutur dan mitra tutur sama-sama mendapat informasi (Widyaningrum, Heny, 2019: 87). Tindak tutur adalah kegiatan yang berlangsung dalam keadaan tertentu baik waktu, tempat, dan situasi dari terjadinya interaksi atau komunikasi dengan satu pokok utama tuturan yang melibatkan seorang penutur dan mitra tuturnya (Chaerdan Agustina, 2010: 47). Selaras dengan pernyataan di atas, Chaer (2004: I6) mengemukakan tindak tutur sebagai gejala individual bersifat psikologis dari kemampuan berbahasa seorang pentur dalam menghadapi situasi tertentu. Untuk itu, seseorang pada saat bertutur dipengaruhi oleh kondisi psikologis yang timbul dari diri si penutur itu sendiri. Misalnya kosa yang dimiliki atau dikuasai di seseorang scara langsung akan diproduksi oleh otak untuk menstimulus tuturan yang akan dihasilkan. Sehingga seseorang yang memiliki keterbatasan penguasaan kosakata akan lebih sulit dalam menyampaikan maksud tuturan berdasarkan apa yang ada di pikirannya. Akibatnya, mitra tutur yang diajak berbicara juga sulit memahami apa yang diucapkan oleh si penutur. Apabila manusia berupaya melakukan tindak tutur berarti ia berupaya menjadi manusia yang berbahasa dengan baik, karena didalamnya ada sebuah pembelajaran bahwa setiap tuturan yang diucapkan harus dipertanggungjawabkan (Rohmadi, 2010). Suatu keadaan yang melibatkan seorang penutur dengan lawan tutur dalam melakukan interaksi atau komunikasi disebut dengan peristiwa tutur. Dalam pembagiannya jenis fungsi tuturan, peristiwa tindak tutur dibedakan menjadi tiga, yakni mencakup tindak tutur lokusi, ilokusi, dan perlokusi. Tindak tutur lokusi, yaitu untuk menyatakan sesuatu yang sesuai dengan keadaan yang ada dan tidak mengandung makna lain atau kiasan. Jadi, mitra tutur diperkenankan untuk meniadakan segala aktivitas terutama menjawab dari tuturan yang ada. Tindak tutur ilokusi, yaitu peristiwa tindak tutur yang berfungsi untuk mengatakan atau menginformasikan sesuatu maksud tertentu. Tuturan ini mengandung makna lain yang apabila penutur mengatakan sesuatu, maka membutuhkan aktivitas atau jawaban dari mitra tuturnya. Tindak tutur perlokusi, yaitu apabila penutur mengatakan sesuatu maka menimbulkan efek dari mitra tuturnya. Bisa dikatakan dengan bahasa lain apabila penutur mengatakan sesuatu, maka maksud dari apa yang diucapkan itu adalah maksud lain (Wijana dan Rohmadi, 2009: 23-25). 
Tindak tutur antar pemain games Mobile Legend ini menggunakan bahasa verbal dan bahasa tulis. Salah satu fungsi bahasa adalah sebagai alat interaksi, maka dengan adanya bahasa, setiap individu dapat melakukan kegiatan komunikasi yang bertujuan untuk menyampaikan maksud tertentu kepada mitra tuturnya (Chaer, 2004: II). Bahasa sendiri dapat besifat Casual Comparatif, yaitu sebaga penyatu komunikasi suatu kelompok juga sebagai pembeda yang mencirikan identitas suatu kelompok tersebut sehingga ada kekhasan pada kelompok tersebut (Hadi, 2017: 26). Tarigan (2005: 6) berpendapat bahwa peran dan fungsi bahasa bergantung pada situasi dan kondisi juga bergantung pada konteksinya. Sehubungan dengan pernyataan tersebut, bahasa juga memiliki beberapa variasi atau ragamnya. Menurut Padmadewi (20I4: 7-8) variasi bahasa adalah sejenis ragam bahasa yang berdasarkan pemakaiannya serta disesuaikan dengan fungsi dan situasinya dengan memperhatikan kaidah-kaidah pokok yang berlaku dalam tindak komunikasi bahasa yang bersangkutan. Proses munculnya variasi bahasa disebabkan karena adanya bentuk interaksi sosial yang dilakukan oleh sekelompok masyarakat atau kelompok yang sangat beragampenuturnya yang tidak homogen (Suandi, 20I4). Kemunculan jenis ragam bahasa dalam pemakaiannya terdapat beberapa macam, diantaranya akrolek, basilek, vulgar, slang, kolokial, jargon, argot, ken, alih kode campur kode, register. Bahasa merupakan salah satu hal yang penting dalam kehidupan manusia karena bahasa digunakan sebagai alat komunikasi. Dalam kehidupan bermasyarakat manusia perlu saling memahami maksud tutran yang disampaikan satu sama lain. Tujuan ini akan tercapai jika manusia saling mampu berkomunikasi dengan baik. Bahasa adalah alat komunikasi yang paling penting (Gross, 1998). Tanpa bahasa manusia tidak dapat berkomunikasi, jika tidak dapat berkomunikasi manusia tidak dapat melangsungkan hidupnya. Itulah yang menjadi alasan bahwa bahasa sangatlah penting bahkan tidak bisalepas dari kehidupan kita dan itu menjadi hal yang paling pokok.

Sejalan dengan hal tersebut, penggunaan bahasa dalam lingkungan, daerah atau suatu lingkup tertentu jelas berbeda satu dengan yang lainnya. Perbedaan pemakaian bahasa di setiap lingkungan sosial atau komunitas tertentu biasa disebut dengan register. Pemakaian bahasa ujaran dalam komunitas gamers seperti yang telah dijelaskan di atas juga termasuk jenis ragam bahasa register, karena bahasa yang diujarkan hanya digunakan pada lingkup komunitas gamers saja dan hanya komunitas tersebut yang paham mengenai ujaran yang diucapkannya.

Bisa dikatakan penggunaan kata atau istilah dalam suatu bidang pekerjaan itu sama, tetapi pemaknaan dan pemanfaatannya yang berbeda, pendapat lain register dapat diurain sebagai suatu bahasa yang biasa dipakai oleh kelompok sosial tertentu dengan istilah dan kosakata khusus yang berkaitan dengan kelompok sosial tersebut. Register sebagai variasi bahasa memiliki ciri-ciri tertentu, yang mencakup tentang leksikogramatis, penanda fonologis yang memiliki fungsi untuk memberi tanda dalam register yang dimaksud, ciri penunjuk berupa kata tertentu, pemilihan pola sintaksis dan retorika khusus, penanda gramatis tertentu, penggunaan istilah dan idiom, dan pemilihan gaya bahasa (Shahamatun, 2013: 2). Register sering pula dikaitkan dengan penggunaan bahasa yang hubungannya dengan konteks bahasa (Aswadi dan Erni, 2017: 2II). Permasalahan register menarik untuk diteliti karena dalam kehidupan tidak sedikit memiliki macam register, karena banyaknya kegiatan yang dilakukan oleh pengguna bahasa sendiri dalam suatu komunitas atau bidang tertentu. Inderasari (2018: 164) mengatakan bahwa seiring berjalannya waktu, register akan mengalami perkembangan, baik dari ranah kosakata dan ungkapan-ungkapannya, maupun perkembangan dalam pemaknaannya. Berdasarkan konsep sosiolinguistik, menurut Sudaryanto, dkk (20I4: 5I5) mengatakan awalnya, pemakaian register dalam suatu kelompok tertentu untuk berkomunikasi dilakukan secara cepat, tepat, dan efisien, kemudian tercipta ungkapan khusus yang dipakai dalam kelompok itu sendiri. Register diciptakan oleh para pengguna bahasa memiliki tujuan tertentu. Diantaranya agar kominikasi lebih efektif. Maksudnya, segala informasi dapat tersampaikan dengan baik sesuai dengan apa yang dikehendaki oleh penutur tanpa membuang-buang waktu serta bahasabahasa yang sulit untuk dipahami (Winanto, 20I4: I3).

Register dalam tindak komunikasi terbagi menjadi berbagai macam jenis, menurut Hadi(2017: 28) meliputi (a) oratorical atau frozen (baku), register yang digunakan oleh seorang pembicara profesional karena pemakaian kaidah bahasanya sudah mantap pada situasi yang khidmat, seperti pembacaan mantra, undang-undang, kitab suci, dan lain sebagainya. (b) deliberative atau formal, yaitu register pada situasi resmi sesuai dengan tujuan untuk memperluas pembicaraan yang disengaja, seperti pidato kenegaraan, peminangan, dan sebagainya. (c) consultative atau usaha, yaitu register yang muncul dalam transaksi kenegaraan, peminangan. (d) casual atau santai, yaitu register yang digunakan dalam situasi tidak resmi. Pada jenis ini banyak digunakannya allegro, yaitu bentuk kata yang diperpendek. (e) intimate atau intim, yaitu register yang digunakan pada situasi antaranggota keluarga. 
Selain dapat dibagi menjadi beberapa jenis, register juga dapat dibagi menjadi beberapa fungsi. Menurut Hadi (2017: 29) menyebutkan bahwa fungsi register antara lain (a) fungsi instrumental, yaitu bahasa yang berorientasi pada pendengar atau lawan tutur. Dalam hal ini, bahasa yang digunakan dimaksudkan untuk mengatur tingkah laku pendengar sehingga lawan tutur mau menuruti apa yang diharapkan penutur. Biasanya menggunakan ungkapan yang menyatakan permintaan, imbauan, atau rayuan. (b) fungsi interaksi, bahasa yang berorientasi pada kontak antara pihak yang sedang berkomunikasi. Hal ini dimaksudkan untuk menjalin dan memelihara hubungan serta memperlihatkan perasaan bersahabat atau solidaritas sosial, biasanya menggunakan ungkapan yang sudah berpola tetap, seperti pada waktu berjumpa, berkenalan, menanyakan keadaan, meminta pamit, dan sebagainya. (c) fungsi kepribadian atau personal, bahasa yang berorientasi pada penutur. Bahasa yang digunakan tersebut untuk menyatukan hal-hal yang bersifat pribadi. (d) fungsi pemecah masalah atau heuristik, pemakaian bahasa yang terdapat dalam ungkapan yang meminta, menurut, atau menyatakan suatu jawaban terhadap masalah atau persoalan. Bahasa yang digunakan biasanya sebagai alat untuk mempelajari segala hal, menyelidiki realitas, mencari fakta, dan penjelasan. (e) fungsi khayal atau imajinasi, bahasa yang berorientasi pada amanat atau maksud yang akan disampaikan. Fungsi ini digunakan untuk mengungkapkan dan menyampaikan pikiran atau gagasan dan perasaan penutur. (f) fungsi informasi, pemakaian bahasa yang berfungsi sebagai alat untuk memberi suat berita atau informasi supaya dapat diketahui orang lain.

Selain terdapat beraneka macam tuturan, games online Mobile Legend juga memiliki dampak positif dan juga negatif bagi para gamers. Dampak positifnya adalah meningkatkan kerja otak, mengajarkan sportivitas, menambah teman, mengasah kemampuan Multi tasking, melatih cara kerja tim dan lebih mengerti serta paham bahasa asing, karena pada permainan Mobile Legend ini menggunakan bahasa Inggris sebagai alat komunikasinya. Sedangkan dampak negatif dari memainkan Mobile Legend adalah berdampak pada efek ketagihan, penasaran, menjadikan pemain terisolasi dari orang disekitarnya, membuat orang menjadi malas, dan berdampak pada psikologis apabila terlalu dipikirkan, serta kurangnya tidur sehingga berdampak buruk pada kesehatan.

Berdasarkan uraian latar belakang dan landasan teori yang dikemukakan di atas, maka dapat diketahui bahwa permasalahan penelitian ini tentang apa saja bentuk, makna, dan fungsi tuturan register dalam permainan Mobile Legend serta apa sajakah dampak yang diterima bagi Gamers, seperti pada penelitian sebelumnya yang sudah pernah dibahas pula mengenai games Mobile Legend Bang Bang dikalangan mahasiswa UIN Sunan Ampel Surabaya dalam tinjauan "One Dimensional' Man Herbert Marcuse. Di mana penelitian tersebut membahas mengenai relevansi Mobile Legend yang dipandang sebagai "Kebutuhan Palsu" dengan menggunakan tinjauan "One Dimensional' Man Herbert Marcuse. Serta penelitian lain yang sudah pernah dilakukan dengan judul Studi Komunikasi Verbal dan Non Verbal Game Mobile Legends: Bang Bang, yang didapatkan hasil penelitian tentang adanya saluran komunikasi verbal dan nonverbal. Saluran komunikasi verbal yang didapatkan berupa discord, microphone dan voice chat dengan bentuk komunikasinya berupa mabar (main bersama), squad (tim atau kelompok bermain dalam game). Kemudian saluran komunikasi nonverbal berupa stiker dan emoji, dengan bentuk komunikasi yang ditemukan berupa istilah-istilah khusus, seperti noob, AFK, GG, GGWP, Savage, Buff, dan sebagainya (Valentina \& Sari, 2018). Berdasarkan atas penelitian yang telah ada sebelumnya tersebut, untuk itu penelitian ini akan membahas mengenai bentuk, makna, dan fungsi tuturan register yang ada dalam permainan Mobile Legend serta pengaruhnya bagi gamers dalam kajian sosiolinguistik.

\section{Metode}

Penelitian ini termasuk jenis penelitian deskriptif kualitatif. Deskriptif kualaitatif dilakukan untuk dapat mengetahui bentuk, makna, dan fungsi tuturan register dalam permainan games online Mobile Legend. Data diperoleh dari dokumentasi pemain games Mobile Legend yang berwujud tuturantuturan antarpemain yang ada pada games Mobile Legend dengan berbagai macam bentuk tuturan, seperti memperingatkan, mengajak, memerintah, memuji, mengkritik, menyatakan kekalahan, dan atau menyatakan kemenangan. Teknik pengumpulan data dalam penelitian ini menggunakan teknik dokumentasi. Analisis data yang digunakan analisis interaktif, dengan langkah -langkah pengumpulan data, mereduksi data, mengklasifikasikan data, menyajikan data, dan menyimpulkan data.

\section{Hasil dan Pembahasan}

Mobile Legend adalah games yang saat ini sedang marak dimainkan oleh kalangan muda bahkan hingga tua. Games ini banyak diminati karena penggunaannya selain mudah, tampilan games-nya juga menarik. Pada saat bermain, seorang gamers selalu mengucapkan ujaran-ujaran yang hanya dimengerti oleh seorang gamers. Ujaran-ujaran 
tersebut digunakan oleh para pemain Mobile legend untuk memperingati, mengajak, memerintah, memuji, mengkritik, menyatakan kekalahan, dan menyatakan kemenangan. Selain itu seorang gamers juga sering kali mengucapkan umpatan-umpatan sebagai ungkapan kekesalan. Kekesalan terjadi apabila games yang dimainkan mati karena terserang oleh musuhnya atau kesal karena dinyatakan kalah dalam satu pertandingan. Ujaran-ujaran yang dimaksudkan tadi merupakan register, yaitu salah satu bagian dari variasi bahasa dalam kajian sosiolinguistik

\section{Bentuk-Bentuk Tuturan Register yang Ada pada Games Online Mobile Legend}

Tuturan adalah bahasa tutur yang digunakan oleh seseorang atau sekelompok manusia dalam ranah tertentu. Dalam sekelompok orang yang bermain games online Mobile Legend, seseorang juga menggunakan tuturan-tuturan khusus yang artinya hanya dimengerti oleh sekelompok itu sendiri. Ada beberapa contoh wujud tuturan yang digunakan oleh pemain Mobile Legend.

\begin{tabular}{|c|c|}
\hline$A$ & : Maen squad yoh \\
\hline & (ayo main squad) \\
\hline B & : Gass. Ndang undangen aku \\
\hline & (Gass, buruan undang aku) \\
\hline A & $\begin{array}{l}\text { : Oke. Ndang } \log \text { in } \\
\text { (oke. Buruan } \log \text { in) }\end{array}$ \\
\hline B & : Yo. Uwes aku (iya, sudah aku) \\
\hline & : woi woi awas di kill wengko. \\
\hline & $\begin{array}{l}\text { Ngaliho! Yoto. First blood ngeyel. } \\
\text { (woi woi awas di kill nanti kamu. }\end{array}$ \\
\hline & Pergi!Yakan. First blood ngeyel.) \\
\hline B & : Lha serku arep ngekill og. Malah mati. \\
\hline & $\begin{array}{l}\text { (Tujuanku sih mau nge-kill. Malah } \\
\text { mati) }\end{array}$ \\
\hline & $\begin{array}{l}\text { : Halahhhh. Noob bakne we. } \\
\text { (Halaahhh. Noob ternyata kamu) }\end{array}$ \\
\hline
\end{tabular}

Gambar I. Contoh tuturan register dalam Mobile Legend

Berdasarkan percakapan di atas ditemukan adanya wujud tuturan register pada permainan Mobile Legend maupun orang yang memainkan games Mobile Legend. Register dibagi menjadi dua yaitu register tunggal dan register kompleks.

\section{Register Tunggal}

Register tunggal adalah bentuk bahasa yang digunakan sebagai pemendekan yang masih bersifat utuh dan berdiri sendiri tanpa afiksasi apa pun (Inderasari, 2018: I7I-172). Dalam Mobile Legend terdapat kata squad yang berarti pasukan, biasanya digunakan oleh pemain Mobile Legend untuk mengajak orang lain untuk bermain bersama. Berbeda dengan maniac. Kata maniac dalam bahasa Indonesia berarti gila. sedangkan dalam game ini, maniac memiliki arti bahwa tim kita berhasil membunuh 4 hero lawan. Sejenis dengan savage. Hanya berbeda jumlah hero yang dibunuh. Savage dalam bahasa Indonesia berarti kejam sesuai dengan makna kata savage dalam games ini yakni berarti bahwa tim kita berhasil membunuh 5 hero lawan. Legendary dalam bahasa Indonesia berarti legendaris. Legendary dalam permainan ini berarti tim kita mendapat delapan kill. Kata unstoppable dalam bahasa Indonesia berarti tak terbendung. Legendary dalam games ini berarti bahwa kita mendapatkan 5 kill. Berbeda dengan shutdown, dalam bahasa Indonesia berarti menutup. Sedangkan pada games Mobile Legend ini kata shutdown berarti bunyi yang berarti kita mati terbunuh oleh lawan pada saat bertempur. Berbeda lagi dengan defeat, dalam bahasa Indonesia berarti mengalahkan. Sedangkan kata defeat dalam games ini berarti tim kita kalah oleh tim lawan dan berakhirnya pertandingan games. Kebalikan dengan victory. Victory dalam bahasa Indonesia berarti kemenangan. Sesuai dengan artinya, Victory dalam games ini adalah peringatan yang menunjukkan kemenangan atas tim lawan. Berbeda lagi dengan noob, dalam bahasa Indonesia noob berarti cupu. Sedangkan arti noob dalam games ini adalah ejekan kepada orang yang mainnya jelek.

\section{Register kompleks}

Register kompleks adalah bentuk bahasa register yang disampaikan sifatnya berupa kalimat yang tidak lengkap yaitu bukan kata yang berdiri sendiri (Inderasari, 20I8: 172). Seperti yang terdapat pada permainan Mobile Legend pada kalimat double kill, sesuai dengan artinya yang berarti berhasil membunuh 2 hero lawan. Pernyataan ini biasanya muncul pada games-nya atau bisa juga gamers ikut mengucapkan kata ini. Berbeda lagi dengan kata lain, seperti You Have Slain an Enemy yang memiliki makna membunuh lawan main. Kata ini biasanya muncul pada saat gamers bermain games, kata ini muncul dari games-nya. Ada lagi Launch Attack yang berarti perintah kepada tim untuk menyerang musuh. Suara ini muncul apabila salah satu anggota tim memerintah kepada tim umtuk bersama-sama menyerang musuh, suara ini biasanya dimunculkan pada saat bertempur melawan musuh atau pada saat hero lawan masih dalam keadaan mati.

Berikut adalah klasifikasi register tunggal dan kompleks:

Tabel I. Bentuk Tuturan Register Tunggal dan Register Kompleks dalam Games Mobile Legend

No Register Tunggal No Register Kompleks

\begin{tabular}{llcl}
\hline I. & Maniac & I & First Blood \\
\hline 2. & Shutdown & 2. & Double Kill \\
\hline 3. & Defeat & 3. & Triple Kill \\
\hline 4. & Savage & 4. & Wiped Out \\
\hline 5. & Squad & 5. & $\begin{array}{l}\text { An Ally Has Been } \\
\text { Slain }\end{array}$ \\
\hline
\end{tabular}




\begin{tabular}{|c|c|c|c|}
\hline 6. & Noob & 6. & $\begin{array}{l}\text { You Have Been } \\
\text { Slain }\end{array}$ \\
\hline 7. & Turret & 7. & Enemy Triple Kill \\
\hline 8. & Unstoppable & 8. & Enemy Savage \\
\hline 9. & Legendary & 9. & Initiate Attack \\
\hline I0. & Executed & I0. & Killing Spree \\
\hline II. & Victory & II. & $\begin{array}{l}\text { Request } \\
\text { Backup/Gather }\end{array}$ \\
\hline \multirow[t]{21}{*}{$\mathrm{I} 2}$. & Lord & I2. & God Like \\
\hline & & I3. & $\begin{array}{l}\text { You Have Slain an } \\
\text { Enemy }\end{array}$ \\
\hline & & I4. & $\begin{array}{l}\text { Your Team } \\
\text { Destroyed a Turret }\end{array}$ \\
\hline & & I5. & $\begin{array}{l}\text { Our Turret } \\
\text { Destroyed }\end{array}$ \\
\hline & & I6. & $\begin{array}{l}\text { Our Base } \\
\text { Underatack }\end{array}$ \\
\hline & & I7. & $\begin{array}{l}\text { An ally has slain the } \\
\text { Turtle }\end{array}$ \\
\hline & & I8. & $\begin{array}{l}\text { Enemy has slain the } \\
\text { Turtle }\end{array}$ \\
\hline & & 19. & $\begin{array}{l}\text { Enemy Has Been } \\
\text { Slain }\end{array}$ \\
\hline & & 20. & Enemy Double Kill \\
\hline & & $2 \mathrm{I}$. & Enemy Maniac \\
\hline & & 22. & Launch Attack \\
\hline & & 23. & Mega Kill \\
\hline & & 24. & Monster Kill \\
\hline & & 25. & $\begin{array}{l}\text { You Destroyed a } \\
\text { Turret }\end{array}$ \\
\hline & & 26. & $\begin{array}{l}\text { Our Turret is } \\
\text { Underatack }\end{array}$ \\
\hline & & 27. & Our Inhibitot \\
\hline & & & $\begin{array}{l}\text { Turret } \\
\text { Underatack }\end{array}$ \\
\hline & & 28. & $\begin{array}{l}\text { An ally has slain } \\
\text { Lord }\end{array}$ \\
\hline & & & $\begin{array}{l}\text { Enemy has slain } \\
\text { Lord }\end{array}$ \\
\hline & & & GG (Good Game) \\
\hline & & $3 \mathrm{I}$. & By one \\
\hline
\end{tabular}

Berdasarkan pada data di atas, dari hasil pengumpulan data pada tuturan Games Mobile Legend diperoleh hasil bahwa terdapat 43 bentuk tuturan dan terbagi menjadi dua macam register, yaitu register tunggal terdapat I2 dan register terdapat $3 \mathrm{I}$ bentuk data register kompleks yang terdapat pada games Mobile Legend. Kedua pola register baik register kompleks dan register tunggal sama-sama telah dipahami dan disepakati oleh kedua pemain dalam pertandingan games Mobile Legend.

\section{Makna Tuturan Register yang Ada pada Games Mobile Legend}

Dalam pola komunikasi wujud tuturan ada berbentuk tuturan verbal da tuturan nonverbal yang masing-masing mengandung maksud dan makna. Makna tuturan merupakan arti atau maksud tuturan yang dilontarkan oleh seseorang atau komunitas tertentu yang biasanya menggunakan tuturan-tuturan khusus. Makna tuturan yang ada pada permainan Mobile Legend merujuk pada maksud atau arti dari kalimat yang dilontarkan oleh para pemainnya. Setiap tuturan maknanya berbeda antara yang satu dengan tuturan yang lainnya.

Berdasarkan bentuk-bentuk tuturan register yang telah diketahui sebelumnya, maka dapat dianalisis makna tuturan register berdasarkan bentukbentuk tersebut pada tabel di bawah ini sebagai berikut:

Tabel 2. Makna Tuturan Register dalam Games Mobile

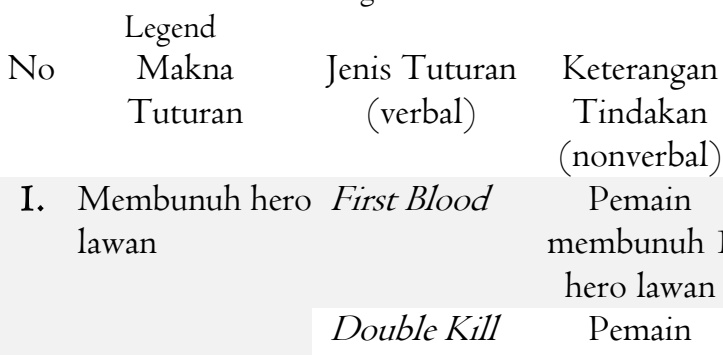
membunuh 2 hero lawan

Triple Kill Pemain membunuh 3 hero lawan

Maniac Pemain membunuh 4 hero lawan

Savage Pemain membunuh 5 hero lawan

2. Kematian Hero Wiped Out 5 hero salah dari tim kita mati

\begin{tabular}{|c|c|}
\hline $\begin{array}{l}\text { An Ally Has } \\
\text { Been Slain }\end{array}$ & $\begin{array}{l}\text { I anggota tim } \\
\text { terbunuh }\end{array}$ \\
\hline $\begin{array}{l}\text { You Have } \\
\text { Been Slain }\end{array}$ & Kita terbunuh \\
\hline $\begin{array}{l}\text { Enemy } \\
\text { Double Kill }\end{array}$ & $\begin{array}{l}\text { Lawan berhasil } \\
\text { membunuh } 2 \\
\text { anggota tim }\end{array}$ \\
\hline $\begin{array}{l}\text { Enemy } \\
\text { Triple Kill }\end{array}$ & $\begin{array}{c}\text { Lawan berhasil } \\
\text { membunuh } 3 \\
\text { anggota tim }\end{array}$ \\
\hline $\begin{array}{l}\text { Enemy } \\
\text { Maniac }\end{array}$ & $\begin{array}{c}\text { Lawan berhasil } \\
\text { membunuh } 4 \\
\text { tim kita }\end{array}$ \\
\hline $\begin{array}{l}\text { Enemy } \\
\text { Savage }\end{array}$ & $\begin{array}{l}\text { Lawan berhasil } \\
\text { membunuh } 5 \\
\text { tim kita }\end{array}$ \\
\hline
\end{tabular}




\begin{tabular}{|c|c|}
\hline Shutdown & $\begin{array}{c}\text { Kita terbunuh } \\
\text { saat melakukan } \\
\text { kill streak }\end{array}$ \\
\hline $\begin{array}{l}\text { An ally has } \\
\text { slain Lord }\end{array}$ & $\begin{array}{c}\text { Tim berhasil } \\
\text { membunuh } \\
\text { Lord }\end{array}$ \\
\hline $\begin{array}{l}\text { An ally has } \\
\text { slain the } \\
\text { Turtle }\end{array}$ & $\begin{array}{c}\text { Tim berhasil } \\
\text { membunuh } \\
\text { Turtle }\end{array}$ \\
\hline $\begin{array}{l}\text { Enemy has } \\
\text { slain Lord }\end{array}$ & $\begin{array}{c}\text { Lawan berhasil } \\
\text { membunuh } \\
\text { Lord }\end{array}$ \\
\hline $\begin{array}{l}\text { Enemy has } \\
\text { slain the } \\
\text { Turtle }\end{array}$ & $\begin{array}{c}\text { Lawan berhasil } \\
\text { membunuh } \\
\text { Turtle }\end{array}$ \\
\hline Executed & $\begin{array}{l}\text { Kita telah mati } \\
\text { karena turret, } \\
\text { minion, jungle } \\
\text { monster, Lord } \\
\text { atau Turtle }\end{array}$ \\
\hline Defeat & $\begin{array}{c}\text { Kekalahan atas } \\
\text { tim lawan }\end{array}$ \\
\hline $\begin{array}{l}\text { You Have } \\
\text { Slain an } \\
\text { Enemy }\end{array}$ & $\begin{array}{l}\text { Membunuh } \\
\text { lawan main }\end{array}$ \\
\hline $\begin{array}{l}\text { Enemy Has } \\
\text { Been Slain }\end{array}$ & $\begin{array}{l}\text { Satu anggota } \\
\text { tim lawan } \\
\text { terbunuh }\end{array}$ \\
\hline
\end{tabular}

Killing Spree Kita mendapat tiga kill

Mega Kill Kita mendapat empat kill

Unstoppable Kita mendapat lima kill

Monster Kill Kita mendapat enam kill

God Like Kita mendapat tujuh kill

Legendary Kita mendapat delapan kill

You Kamu berhasil

Destroyed a menghancurkan

Turret turret

Your Team Anggota tim

Destroyed a berhasil meng-

Turret hancurkan turret

5. Kemenangan di Victory Kemenangan akhir pertandingan

6. Memberi Launch Perintah perintah Attack kepada tim untuk

\begin{tabular}{|c|c|c|}
\hline \multirow{5}{*}{$\begin{array}{l}\text { Memberi } \\
\text { petanda }\end{array}$} & & $\begin{array}{c}\text { menyerang } \\
\text { musuh }\end{array}$ \\
\hline & $\begin{array}{l}\text { Initiate } \\
\text { Attack }\end{array}$ & $\begin{array}{c}\text { Perintah } \\
\text { kepada tim } \\
\text { untuk mundur }\end{array}$ \\
\hline & $\begin{array}{l}\text { Request } \\
\text { Backup/Gat } \\
\text { her }\end{array}$ & $\begin{array}{c}\text { Berkumpul } \\
\text { atau meminta } \\
\text { bantuan karena } \\
\text { musuh lebih } \\
\text { banyak }\end{array}$ \\
\hline & $\begin{array}{l}\text { Our Turret } \\
\text { is } \\
\text { Underatack }\end{array}$ & $\begin{array}{l}\text { Salah satu } \\
\text { turret dari tim } \\
\text { kita sedang } \\
\text { diserang }\end{array}$ \\
\hline & Our Turret & Salah satu \\
\hline \multirow{5}{*}{ 8. Mengajak teman } & Destroyed & $\begin{array}{c}\text { turret dari tim } \\
\text { kita telah } \\
\text { hancur }\end{array}$ \\
\hline & $\begin{array}{l}\text { Our } \\
\text { Inhibitor } \\
\text { Turret is } \\
\text { Underatack }\end{array}$ & $\begin{array}{c}\text { Salah satu } \\
\text { turret } \\
\text { penghadang } \\
\text { dari tim kita } \\
\text { sedang diserang }\end{array}$ \\
\hline & $\begin{array}{l}\text { Our Base } \\
\text { Underatack }\end{array}$ & $\begin{array}{l}\text { Base kita } \\
\text { sedang di } \\
\text { serang }\end{array}$ \\
\hline & Squad & $\begin{array}{l}\text { Mengajak } \\
\text { bermain } \\
\text { kelompok }\end{array}$ \\
\hline & By one & $\begin{array}{c}\text { Mengajak } \\
\text { bermain satu } \\
\text { lawan satu }\end{array}$ \\
\hline 9. Memuji teman & $\begin{array}{l}\text { GG (Good } \\
\text { Game) }\end{array}$ & $\begin{array}{l}\text { Bermainnya } \\
\text { bagus }\end{array}$ \\
\hline $\begin{array}{l}\text { I0. Mengejek } \\
\text { teman/lawan }\end{array}$ & Noob & $\begin{array}{c}\text { Bermainnya } \\
\text { jelek dan selalu } \\
\text { mati }\end{array}$ \\
\hline $\begin{array}{l}\text { II. Istilah nama } \\
\text { dalam Mobile } \\
\text { Legend }\end{array}$ & $\begin{array}{l}\text { Lord } \\
\text { Turret }\end{array}$ & $\begin{array}{l}\text { Berarti tuan } \\
\text { Berarti menara }\end{array}$ \\
\hline
\end{tabular}

Berdasarkan analisis pada tabel di atas, tersaji wujud makna yang dimunculkan dari sebuah tuturan baik verbal dan nonverbal. Sehingga bisa diketahui bahwa bentuk tuturan register dalam games Mobile Legend memiliki I I makna, yakni bermakna

(I) membunuh hero lawan, (2) Kematian Hero dari tim kita mati, (3) kekalahan di akhir pertandingan, (4) Kematian Hero dari tim lawan mati, (5) kemenangan di akhir pertandingan, (6) memberi perintah, (7) memberi pertanda, (8) mengajak teman, (9) memuji teman, (IO) mengejek teman/lawan, dan (II) istilah nama dalam Mobile Legend. Dari sebelas makna tersebut akan dijelaskan sebagai berikut.

Membunuh hero lawan 
Makna kejadian tindakan membunuh hero lawan dilakukan pada saat bertemu dengan musuh bermainnya atau pada saat saling menyerang. Biasanya tindakan ini dilakukan agar musuh kewalahan sehingga kemenangan dapat berpihak di pihak yang berhasil membunuh hero dan turret musuh. Misal pada tuturan First Blood ungkapan yang disampaikan saat Pemain membunuh I hero lawan, First Blood ungkapan yang disampaikan saat Pemain membunuh 2 hero lawan, dsb.

\section{Kematian Hero, turret, atau lord dari tim kita}

Makna kejadian tindakan kematian Hero, turret, atau lord dari tim kita, terjadi pada saat dibunuh oleh lawan serta bertemu pada saat saling menyerang. Sehingga dapat dinyatakan kalah pada saat menyerang, bukan dinyatakan kalah dalam satu pertandingan. Misalnya tuturan Wiped Out tuturan muncul pada saat 5 hero salah satu tim mati, An Ally Has Been Slain I tuturan pada saat satu anggota tim terbunuh, dsb.

\section{Kekalahan di akhir pertandingan}

kekalahan di akhir pertandingan adalah kekalahan apabila semua hero dari tim kita sudah tidak mampu menghalau musuh sehingga menimbulkan kematian beberapa kali dan akhirnya wilayah dari tim kita dikuasai oleh musuh/tim penyerang yang menghancurkan minion (pasukan yang biasanya selalu muncul membantu tim) dan juga turret. Apabila semua turret sudah runtuh termasuk turret terakhir (turret paling besar), tim tersebut dinyatakan kalah dalam satu pertandingan. Misal pada tuturan Defeat menyatakan Kekalahan atas tim lawan.

\section{Kematian Hero, turret atau lord dari tim lawan}

Hero, turret atau lord dari tim lawan mati terjadi pada saat tim kita berhasil membunuh dari tim lawan. Sehingga tim kita dinyatakan menang, tetapi menang dalam artian dapat membunuh salah satu anggota dari tim lawan, bukan menang dalam satu pertandingan. Misal pada tuturan You Have Slain an Enemy yang berarti Membunuh lawan main,dll.

\section{Kemenangan di akhir pertandingan}

Kejadian tindakan kemenangan di akhir pertandingan adalah kemenangan apabila semua hero, turret, dan semua anggota dari tim lawan dapat dikalahkan. Termasuk hancurnya turret terakhir yaitu turret yang paling besar hancur. Misal pada tuturan Victory berarti Kemenangan tim lawan,dll.

\section{Memberi perintah}

Memberi perintah dilakukan pada saat situasi mendesak seperti menyerang lawan, lawan berada di dekat tim kita dan berada dalam incaran lawan. Perintah ini dilakukan untuk keselamatan timnya sendiri. Misal pada tuturan Squad berarti Perintah kepada tim untuk menyerang musuh.

Memberi pertanda
Memberi pertanda dilakukan apabila sesama anggota mengingatkan apabila ada serangan dari musuh. Situasi yang dimaksudkan disini tingkatannya masih hanya peringatan, jadi masih dibawahnya perintah. Misal pada tuturan Our Turret is Underatack Salah satu turret dari tim kita sedang diserang.

\section{Mengajak teman}

Mengajak teman dilakukan apabila seseorang ingin mengajak bermain Mobile Legend bersama. Misal pada tuturan Squad Mengajak bermain kelompok.

\section{Memuji teman}

Memuji teman dilakukan apabila ada teman yang bermainnya bagus sehingga menimbulkan keuntungan bagi timnya. Selain itu kalimat pujian ini bisa dicapkan apabila seseorang melihat orang lain memainkan Mobile Legend dengan bagus dan menimbulkan kemenangan. Misal pada tuturan GG (Good Game) bermakna bermainnya bagus.

\section{Mengejek teman/lawan}

Mengejek teman/lawan biasanya dilakukan apabila ada orang yang mainnya jelek, sehingga pada tuturan Noob berarti bermainnya jelek dan selalu mati.

\section{Istilah nama dalam Mobile Legend}

Istiah nama dalam Mobile Legend yang dimaksudkan di sini adalah nama-nama yang ada pada Mobile Legend bisa berupa nama hero ataupun selain hero. Misalnya Lord and Turret bermakna Tuan dan Menara.

Dapat disimpulkan bahwa terdapat berbagai jenis tuturan register yang masing-masing menggandung makna khusus. Masing-masing tuturan tersebut telah disepakati dan dipahami oleh keduabelah pihak antar pemain Games Mobile Legend sehingga keefektifan komunikasi dengan mudah tersampaikan dan terpahami secara bersama dalam permainan. Turutan register tersebut hanya bisa terpahami oleh orang-orang yang sudah terbiasa memainkan games tersebut dengan makna yang berbeda-beda.

\section{Fungsi Tuturan yang Ada pada Games Online Mobile Legend}

Fungsi tuturan berarti kegunaan dari tuturan itu sendiri yang memiliki peran penting dan memiliki tujuan tertentu. Fungsi tuturan yang digunakan dalam permainan Mobile Legend memiliki tujuan dan maksud tertentu sebagai komunikasi dalam memainkan game tersebut.

Berdasarkan dari bentuk-bentuk tuturan register di atas, maka dapat diklasifikasikan berdasarkan fungsi tuturannya, yang dibagi menjadi 7 kategori, yakni tuturan yang berfungsi untuk memperingatkan tim karena sedang diserang, 
mengajak untuk bermain games Mobile Legend, memerintah tim untuk menyerang atau mundur, memuji tim atau pemain lain, mengkritik tim atau pemain lain, menyatakan kemenangan tim, dan menyatakan kekalahan tim. Fungsi-fungsi tuturan tersebut dapat diketahui sebagai berikut:

\section{Fungsi Memperingatkan Tim}

Fungsi memperingatkan dapat diartikan sebagai tuturan untuk memberitahukan sesuatu sebagai bentuk kehati-hatian sebelum peristiwa terjadi. Dalam permainan Mobile Legend ditemukan 4 register yang termasuk dalam fungsi memperingatkan diantaranya, yaitu:

\section{a. Our Turret is Underatack.}

Suara tersebut, muncul ketika salah satu turret dari tim kita sedang diserang. Terlihat bahwa pada kata diserang dapat diartikan sebagai bentuk peringatan.

\section{b. Our Turret Destroyed}

Suara tersebut muncul ketika salah satu turret dari tim kita telah hancur. Pada kata telah hancur. Hal ini menandakan sebuah peringatan kepada pemain lain untuk memperkuat pertahanan dan meningkatkan kewaspadaan karena berkurangnya satu anggota tim.

\section{c. Our Inhibitor Turret is Underatack}

Suara tersebut berarti bahwa salah satu turret penghadang dari tim kita sedang diserang. Kata diserang menandakan bahwa peringatan kepada seluruh anggota tim untuk meningkatkan kewaspadaan.

\section{d. Our Base Underatack}

Suara tersebut berarti bahwa base kita sedang di serang. Untuk itu, kata ini dapat diartikan sebagai fungsi memperingatkan.

\section{Fungsi Mengajak Bermain}

Tuturan yang berfungsi sebagai ajakan/mengajak dapat diartikan sebagai bentuk ajakan agar dapat bermain bersama, dalam permainan Mobile Legend ditemukan 2 register yang termasuk dalam fungsi ini diantaranya, yaitu:

a. Squad

Register ini muncul ketika kita ingin mengajak bermain games Mobile Legend kepada temanuntuk berada dalam satu kelompok.

\section{b. By one}

Register ini muncul ketika kita ingin mengajak teman bermain satu lawan satu.

\section{Fungsi Memerintah Tim}

Tuturan memerintah dapat diartikan sebagai tuturan yang dimaksudkan untuk menyuruh lawan untuk melakukan sesuatu. Dalam permainan Mobile Legend ditemukan 3 register yang termasuk dalam fungsi memerintah diantaranya, yaitu:

\section{a. Launch Attack}

Suara ini muncul, menandakan bahwa tim diberi perintah untuk menyerang musuh. Kata attack dalam bahasa Indonesia berarti menyerang. Menyerang biasa digunakan dalam kalimat perintah.

\section{b. Initiate Attack}

Suara ini muncul, menandakan bahwa tim diberi perintah untuk mundur. Hal ini biasa terjadi pada saat tim musuh lebih banyak menyerang dan tim kita kewalahan menghadapinya. Daripada terbunuh lebih baik untuk mundur.

\section{c. Request Backup/Gather}

Suara ini muncul sebagai pertanda perintah untuk berkumpul atau meminta bantuan karena tim musuh lebih banyak pada saat bertempur.

\section{FungsiMemuji Tim}

Tuturan menyanjung dapat diartikan sebagai pemberian penghargaan atas sesuatu hal yang membahagiakan. Dalam permainan Mobile Legend ditemukan I register yang termasuk dalam fungsi menyanjung diantaranya, yaitu:

\section{a. $G G$ (Good Game)}

Register ini muncul ketika seorang pemain memuji atau menyanjung pemain lain bahwa permainannya bagus.

\section{Fungsi Mengkritik Tim}

Tuturan mengkritik dimaksudkan untuk dapat memberikan penilaian atau komentar mengenai suatu hal yang baik atau buruk yang bersifat membangun atau menjatuhkan. Dalam permainan Mobile Legend ditemukan I register yang termasuk dalam fungsi mengkritik diantaranya, yaitu:

a. Noob

Register ini muncul ketika seorang pemain mengkritik pemain lain karena permainannya jelek dan selalu mati.

\section{Fungsi Kemenangan Tim}

Fungsi tuturan kemenangan dimaksudkan sebagai bentuk rasa bahagia yang dilontarkan dalam permainan ini. Tuturan kemenangan dibagi menjadi dua kategori, yakni kategori kemenangan di tengah pertandingan dan kemenangan akhir. Dalam permainan Mobile Legend ditemukan I8 register kemenangan kategori kemenangan di tengah pertandingan dan I kategori kemenangan akhir. Yang termasuk dalam fungsi kemenangan, diantaranya, yaitu:

Kemenangan Di Tengah Pertandingan.

a. First Blood

Suara ini muncul dalam games Mobile Legend apabila pemain berhasil membunuh hero lawan untuk yang pertama kalinya. Pemain Mobile Legend biasanya merasa senang karena telah berhasil membunuh satu hero lawan.

b. Double Kill 
Suara ini muncul apabila pemain berhasil membunuh dua hero lawan secara berturut-turut dalam waktu yang singkat dalam satu pertandingan. Selain suara yang muncul dari games, seorang gamers juga bisa mengungkapkan kata ini karena ia dapat membunuh dua hero lawan secara berturut-turut.

c. Triple Kill

Suara ini muncul apabila pemain berhasil membunuh tiga hero lawan secara berturut-turut dan dalam waktu yang singkat dalam satu pertandingan. Selain suara yang muncul dari games, seorang gamers juga bisa saja mengungkapkan kata ini sebagai tanda kesenangannya karena berhasil membunuh hero lawan.

\section{d. Maniac}

Suara ini muncul apabila pemain berhasil membunuh empat hero lawan secara berturut-turut dalam waktu yang singkat dan tidak mati dalam satu pertandingan.

e. Savage

Suara ini muncul apabila pemain berhasil membunuh lima hero lawan secara berturut-turut dalam waktu yang singkat dan dalam satu pertandingan. Seorang gamers biasanya senang dan sedikit puas karena telah berhasil membunuh lima hero lawan.

\section{f. Wiped Out}

Suara ini muncul apabila kelima hero salah satu tim mati. Tim yang berhasil melakukan Wiped Out, memiliki kesempatan yang lebih mudah untuk menyerang musuh. Karena kelima hero sudah dibunuh.

g. You Have Slain an Enemy

Register ini dapat diartikan bahwa kamu telah melakukan kill. Maksudnya adalah bahwa kamu telah membunuh lawan mainmu.

h. Enemy Has Been Slain

Register ini dapat diartikan bahwa salah satu anggota dari tim lawan berhasil terbunuh.

i. Killing Spree

Suara ini muncul, menandakan bahwa kita mendapat tiga kill tanpa terbunuh oleh musuh.

j. Mega Kill

Suara ini muncul, menandakan bahwa kita mendapat empat kill tanpa terbunuh oleh musuh.

k. Unstoppable

Suara ini muncul, menandakan bahwa kita mendapat lima kill tanpa terbunuh oleh musuh.

\section{Monster Kill}

Suara ini muncul, menandakan bahwa kita mendapat enam kill tanpa terbunuh oleh musuh.

m. God Like

Suara ini muncul, menandakan bahwa kita mendapat tujuh kill tanpa terbunuh oleh musuh.

n. Legendary
Suara ini muncul, menandakan bahwa kita mendapat delapan kill tanpa terbunuh oleh musuh.

o. You Destroyed a Turret

Suara ini muncul ketika kamu berhasil menghancurkan turret.

\section{p. Your Team Destroyed a Turret}

Suara tersebut muncul ketika salah satu anggota tim kita berhasil menghancurkan sebuah turret.

q. An ally has slain Lord

Suara tersebut muncul ketika salah satu anggota tim kita berhasil membunuh Lord.

r. An ally has slain the Turtle

Suara tersebut muncul ketika salah satu anggota tim kita berhasil membunuh Turtle. Kemenangan Akhir.

a. Victory

Suara tersebut muncul, menandakan kemenangan atas tim lawan.

\section{Fungsi Kekalahan Tim}

Tuturan kekalahan dimaksudkan untuk memberitahukan bahwa kita mengalami suatu kejadian yang tidak diinginkan yang dapat mengakibatkan suatu kekalahan. Kekalahan ini dapat di bedakan menjadi dua kategori, yakni kekalahan pada pertengahan pertandingan dan kekalahan akhir. Dalam permainan Mobile Legend ditemukan IO register kekalahan kategori kekalahan di tengah pertandingan dan I kategori kekalahan akhir. Yang termasuk dalam fungsi kekalahan, diantaranya, yaitu: Kekalahan di Tengah Pertandingan

a. An Ally Has Been Slain

Register tersebut menandakan bahwa salah satu dari anggota timtelah terbunuh.

b. You Have Been Slain

Register tersebut menandakan bahwa kamu telah terbunuh.

\section{c. Enemy Doble Kill}

Register tersebut menandakan bahwa dari tim lawan berhasil membunuh (kill) dua tim kita (Ally) dalam waktu yang singkat.

\section{d. Enemy Triple Kill}

Register tersebut menandakan bahwa dari tim lawan berhasil membunuh (kill) tiga tim kita (Ally) dalam waktu yang singkat.

\section{e. Enemy Maniac}

Register tersebut menandakan bahwa dari tim lawan berhasil membunuh (kill) empat tim kita (Ally) dalam waktu yang singkat.

f. Enemy Savage

Register tersebut menandakan bahwa dari tim lawan berhasil membunuh (kill) empat tim kita (Ally) dalam waktu yang singkat.

g. Shutdown 
Suara ini muncul apabila kamu terbunuh saat mencetak kill streak (sudah kill tiga atau lebih).

h. Enemy has slain Lord

Suara tersebut muncul ketika salah satu anggota tim lawan berhasil membunuh Lord.

i. Enemy has slain the Turtle

Suara tersebut muncul ketika salah satu anggota tim lawan berhasil membunuh Turtle.

j. Executed

Suara tersebut muncul sebagai pertanda bahwa kita telah mati karena turret, minion, jungle, monster, Lord atau Turtle.

Kekalahan Akhir

a. Defeat

Register tersebut menandakan bahwa kekalahan atas tim lawan.

Pengaruh Games Online Mobile Legend Bagi Gamers

Penggunaan atau memainkan permainan games online Mobile Legend tentu tidak dibenarkan jika dilakukan terus-menerus. Hal ini tentu akan berdampak pada psikologi tiap individu yang gemar bermain game. Psikologi dapat diartikan sebagai ilmu yang mempelajari tingkah laku manusia, yakni interaksi manusia dengan dunia sekitarnya, seperti manusia dengan manusia, manusia dengan hewan, manusia dengan iklim, manusia dengan kebudayaan, dan lain sebagainya (Natsir, 2017: 22). Untuk itu, berdasarkan uraian pembahasan yang telah di paparkan di atas, maka dapat disimpulkan dampak positif dan negatif dari adanya penggunaan games online Mobil Legend adalah sebagai berikut:

\section{Dampak Positif}

a. Mempermudah komunikasi antarpemain Mobile Legend

Dengan adanya ujaran-ujaran, maka hal tersebut mempermudah gamers dalam melakukan komunikasi antar pemain dalam permainan tersebut dimana pemain yang satu dengan yang lain lebih paham apa yang di maksudkan. Bahasanya lebih mudah dimengerti oleh para pemainnya itu sendiri sehingga bisa mempererat keakraban sesama pecinta games Mobile Legend

b. Meningkatkan kerja otak pemain games Mobile Legend

Permainan ini membutuhkan banyak kerja dari otak, karena apabila seseorang memainkannya, maka harus memiliki kemampuan dan teknik bermain yang lincah, cerdas dan tidak mudah emosi. Maka dari itu permainan ini dikatakan permainan kerja otak.

c. Mengajarkan sportivitas dalam kelompok atau tim

Permainan ini dapat menumbuhkan sportivitas, baik saat memainkan, setelah memainkan games ini atau pada penerapan dikehihidupannya. Pemain Mobile Legend dikatakan menumbuhkan sportivitas karena pada games ini terbiasa dituntut untuk jujur dan terbuka mengenai keunggulan atau kemenangan lawan dan mengakui kelemahan atau kesalahan dari diri kita sendiri. Sehingga hal ini bisa diterapkan oleh si pemain pada saat bermain games atau di kehidupan nyatanya.

d. Menambah teman dan melatih cara kerja tim Permainan ini membutuhkan banyak pemain dalam satu tim, untuk itu, ketika ada orang yang belum kenal tetapi sama-sama menyukai permainan ini otomatis mereka akan dapat berkenalan sehingga dapat menambah teman. Tentunya juga dapat melatih cara kerja tim karena pada permainan ini dituntut untuk kompak dan saling mengerti dengan timnya sendiri agar dapat berhasil memenangkan games ini.

e. Lebih mengerti serta paham bahasa asing bagi pemainnya/gamers

Pemain games ini dapat menambah kosakata bahasa asing, karena sebagian besar percakapan yang terdapat pada game ini menggunakan bahasa asing yakni bahasa Inggris. Hal tersebut bisa membantu para gamers untuk lebih paham mengenai kosakata bahasa Inggris yang bisa diterapkan dikehidupan nyatanya.

f. Lebih meningkatkan kefokusan bagi gamers

Pemain permaian Mobile Legend ini akan lebih bisa menajamkan kefokusannya daripada orang yang tidak memainkan game ini. ini dikarenakan dalam permainan ini, para gamers dituntut untuk memiliki kefokusan yang tajam dan tinggi untuk dapat memenangkan game ini. Apabila gamers tidak fokus memainkan games Mobile Legend ini dan masih memperhatikan hal lain, maka dapat dipastikan ia kalah dalam pertandingan. Karena musuh siap menyerang kapan saja.

g. Pemain/gamers lebih dapat berpikir maju untuk menentukan strategi dalam permainan tersebut

Selain dengan ketelitian, games ini juga menuntut adanya ketajaman dalam pikiran, untuk menentukan strategi seperti apa yang digunakan agar tidak mendapat serangan dari musuh ataupun kekalahan. Jadi para gamers biasa merancang strategi bagaimana caranya untuk mengalahkan musuh. Hal tersebut bisa berpengaruh pada kehidupannya seharihari dalam menyusun sebuah kegiatan maka ia sudah terbiasa dalam merancang strategi terbaiknya.

h. Menambah pengetahuan pemain/gamers tentang teknologi secara baik

Dengan kita bermain permainan ini, tentunya kita dapat belajar ataupun menambah pengetahuan kita tentang teknologi dengan permainan ini, selain itu kita juga dapat sering berkomunikasi menggunakan bahasa register seperti yang sudah di jelaskan di atas, dengan nyaman dan dimengerti oleh semua pemainnya. Orang yang memainkan game ini 
akan mengerti betapa canggihnya teknologi di era modern ini. Mereka yang tidak memainkan games ini pasti tidak akan tahu bagaimana kecanggihan games Mobile Legend yang ada dan akan lebih gaptek.

i. Membantu pemain/gamers menghilangkan kepenatan pekerjaan sehari-hari

Dengan adanya permainan ini, dapat membantu seseorang yang sedang mengalami stres ataupun kepenatan dengan pekerjaan sehari-hari. Maka dari itu, dengan memainkan permainan ini, bagi sebagian orang dapat menghilangkan semua beban yang dirasa berat tersebut. Karena orang yang terbiasa bermain games akan merasa senang saat memainkan permainan ini apalagi jika ia dapat membunuh hero lawan sekaligus dapat memenangkannya dari musuh, hal ini menimbulkan kebahagiaan dan kebanggaan tersendiri bagi gamers.

\section{Dampak Negatif}

a. Pemain/gamers akan sering berkata kasar

Seringnya memainkan games ini, Gamers tidak hanya akan mengucapkan banyak umpatan pada saat sedang bermain games saja, tetapi dia juga akan memiliki penguasaan bahasa atau kosakata kasar yang pasti akan digunakan juga pada kehidupan sehari-hari. Umpatan atau kata kasar yang diucapkan oleh gamers adalah sebagai wujud kekesalan karena ia dibunuh oleh lawan mainnya atau dia kalah dalam permainan tersebut. Hal itu berdampak buruk pada komunikasinya karena apabila mereka sudah terbiasa berkata kasar/kotor pada saat memainkan games, maka kosakata yang digunakannya dalam berbicara pun akan otomatis mengikuti pada saat ia bermain games.

b. Menjadikan pemain terisolasi dari orang di sekitarnya

Sering memainkan permainan ini dapat membuat diri menjadi orang yang penyendiri karena pada permainan Mobile Legend ini adalah games online yang pemainnya bisa memainkan games secara online dan tidak bertatap muka secara langsung. Jadi seseorang bisa terisolasi dari lingkungannya karena tidak pernah berbaur dengan lingkungannya dan senang menyendiri keasikan dengan games yang dimainkannya sehingga berkelanjutan dengan mengisolasi dirinya dari orang-orang disekitarnya.

c. Membuat pemain/gamers menjadi malas

Terlalu sering memainkan games ini dapat menjadikan pemainnya menjadi orang yang malas, karena mereka tidak mau melakukan aktivitas lain selain bermain games Mobile Legend. Gamers terlalu keasyikan dengan keseruan games yang dimainkan sehingga mereka hanya berdiam diri dan terus melanjutkan games yang dimainkannya.

d. Kurangnya tidur sehingga berdampak buruk pada kesehatan pemain/gamers
Para gamers biasanya terlalu asyik bermain games ini hingga larut malam bahkan hingga menjelang pagi hanya untuk mendapatkan kemenangan atau mendapatkan kepuasan batinnya. Hal tersebut akan mengakibatkan para gamers kurang tidur dan lama-kelamaan akan berdampak juga pada kesehatan dan kekebalan tubuh yang menurun karena kebanyakan begadang.

e. Pemain/gamers akan mengalami kecanduan ketika ia bermain terus-menerus

Seringnya bermain games ini membuat pemainnya menjadi ingin terus menerus memainkan game ini. Terutama mereka yang menang pertandingan, mereka akan mengulangi game yang dimainkannya berharap akan mendapatkan kemenangan lagi setelahnya. Lama-kelamaan ia mengalami kecanduan yang bahkan tidak dapat disembuhkan.

f. Pemain/gamers dapat melalaikan pekerjaan lain karena sibuk dan asyik bermain games

Karena keasyikan bermain games ini, sering kali pemain games ini melalaikan pekerjaan yang seharusnya sudah menjadi kewajibannya untuk dikerjakan. Bagaimanapun juga pekerjaan adalah hal yang utama yang harus dikedepankan. Berbeda dengan gamers, mereka akan lebih mengutamakan memainkan games. Hal ini tentu akan berdampak buruk juga pada orang lain, karena orang lain muak dengan apa yang dilakukannya.

g. Pemain/gamers akan membuang banyak waktu dengan sia-sia karena memainkan games ini secara terus-menerus

Masih berkaitan dengan hal yang sama. Ketika banyak dan sering bermain games ini, maka pemain akan kehilangan banyak waktu bagi orang awam. Bagi gamers bermain games ini adalah suatu keasyikan dan kepuasan batin. Terkadang juga banyak berpengaruh bagi lingkungannya dan banyak mendapat marah dari orang lain.

\section{Simpulan}

Berdasarkan pembahasan mengenai tuturan register dalam games online Mobile Legend, dapat disimpulkan bahwa terdapat berbagai jenis tuturan register yang masing-masing menggandung makna khusus. Masing-masing tuturan tersebut telah disepakati dan dipahami oleh keduabelah pihak antarpemain Games Mobile Legend sehingga keefektifan komunikasi dengan mudah tersampaikan dan terpahami secara bersama dalam permainan. Turutan register tersebut hanya bisa terpahami oleh orang-orang yang sudah terbiasa memainkan games tersebut. Adapun fungsi tuturan yang disampaikan tak lain untuk mejalin komunikasi sehingga pertandingan berjalan dengan lancar. Berdasarkan fungsinya dapat 
diklasifikasikan berdasarkan fungsi tuturannya, yang dibagi menjadi 7 kategori, yakni tuturan yang berfungsi untuk memperingatkan tim karena sedang diserang, mengajak untuk bermain games Mobile Legend, memerintah tim untuk menyerang atau mundur, memuji tim atau pemain lain, mengkritik tim atau pemain lain, menyatakan kemenangan tim, dan menyatakan kekalahan tim.

Terlepas dari adanya hal tersebut, permainan Mobile Legend ini juga banyak menimbulkan pengaruh bagi gamers, baik itu pengaruh positif maupun negatif. Pengaruh-pengaruh ini akan menimbulkan banyak manfaat dan banyak pula keburukannya baik pengaruhnya dalam bahasa, tindakan, berpikir, dan bersisosial terhadap lingkungan sekitar. Untuk itu saran gamers sangat diperlukan agar dapat lebih memainkan permainan ini secara lebih bijak lagi, sehingga terhindar dari pengaruh-pengaruh negatif yang tanpa sadar ditimbulkan dari seringnya memainkan permainan ini.

\section{Persantunan}

Terima kasih kepada Allah Swt., dosen pembimbing mata kuliah Sosiolinguistik, temanteman yang telah menyemangati maupun semua pihak yang membantu terselesaikannya artikel ini.

\section{Daftar Pustaka}

Aswadi, Dana, E. S. (2017). Penggunaan Register Berupa Nomina Di Kalangan Pedagang Tradisional Pasar Terapung Kota Banjarmasin. Jurnal Stilistika, 2(2), 2IO-22I.

Chaer, Abdul dan Agustina, L. (2010). Sosiolinguistik Perkenalan Awal. Jakarta: Rineka Cipta.

Chaer, A. (2004). Psikolinguistik: Kajian Teoritik. Jakarta: Rineka Cipta.

Gross, H. (1998). Einführung in die germanistiche Linguistik. München: Iudicium verlag $\mathrm{GmbH}$.

Hadi, I. (2017). Register Pedagang Buah: Studi Pemakaian Bahasa Kelompok Profesi Di Kota Padang. Jurnal Metalingua, I5(I), 25-40.

Inderasari, Elen, W. O. (2018). Pemakaian Register Bahasa Kru Bus AKAP Di Terminal Tirtonadi Surakarta. Jurnal Dialektika, 5(2), I59-I78.

Isnaniah, S. (20I3). KAJIAN SOSIOLINGUISTIK TERHADAP BAHASA DAKWAH AKTIVIS DAKWAH KAMPUS ( ADK ) SURAKARTA. Jurnal KARSA, 2I(2), 270-284.

Natsir, N. (20I7). Hubungan psikolinguistik dalam pemerolehan dan pembelajaran bahasa. Jurnal Retorika, IO(I), 20-29.

Padmadewi, D. (20I4). Sosiolinguistik. Yogyakarta: Graha Ilmu.

Rohmadi, M. (2010). Pragmatik: Teori dan analisis. Surakarta: Yuma Pustaka.

ROSITA, FARIDA YUFARLINA, D. K. (20I9). EKSPRESI BAHASA DAN PERSPEKTIF
PADA BERITA PILPRES 2019 DI MEDIA ONLINE DETIK.COM. Jurnal Hasta Wiyata, $7(2), \mathrm{I} I-\mathrm{I} 2$.

Shahamatun, A. D. (2013). Pemakaian Register Profesi Bidan di Klinik dan Rumah Sakit Bersalin di Delata Mutiara Sukodono Sidoarjo. Jurnal Skriptorium, 2(2), I-I2.

Suandi, I. N. (20I4). Sosiolinguistik. Yogyakarta: Graha Ilmu.

Sudaryanto, Memet, Sumarwati, E. S. (2014). Register Anak Jalanan Kota Surakarta. Jurnal Basastra, I(3), 5I4-528.

Tarigan, H. G. (2005). Pengajaran Wacana. Bandung: Angkasa.

Valentina, E., \& Sari, W. P. (2018). Studi Komunikasi Verbal dan Non Verbal Game Mobile Legends: Bang Bang. Koneksi, 2(2), 300-306.

Widyaningrum, Heny Kusuma, C. H. (2019). Bentuk Lokusi, Ilokusi, Dan Perlokusi Siswa Dalam Pembelajaran Tematik. Jurnal Bahastra, 39(2), 86$9 I$.

Wijana, I Dewa Putu. Rohmadi, M. (2009). Analisis Wacana Pragmatik Kajian Teori dan Analisis. Surakarta: Yuma Pustaka.

Winanto, Y. (2014). Register Sepak Bola Acara Lensa Olahraga Di Antv. Universitas Muhammadiyah Surakarta. 